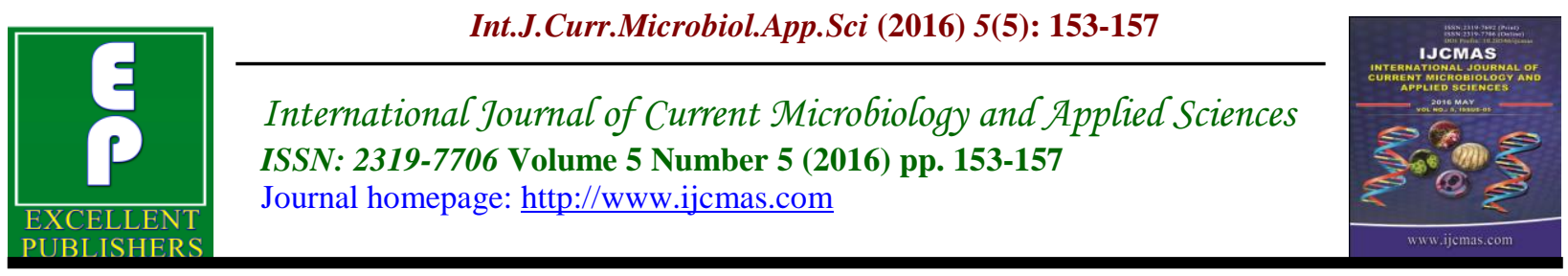

Original Research Article

http://dx.doi.org/10.20546/ijcmas.2016.505.016

\title{
Isolation of Potentially Pathogenic Bacteria from Reusable Venesection Tourniquets in a Tertiary Care Hospital
}

\author{
C. Siva Kalyani, Ramalakshmi Koripella* and Sk. Najar Valli \\ B-101, Clover Majestic Towers, RK Beach Road, Visakhapatnam, Andhra Pradesh, India \\ *Corresponding author
}

\section{Keywords \\ Tourniquets, MROs, \\ Hospital acquired the infection, \\ MRSA, \\ Surveillance.}

\section{Article Info}

Accepted:

12 April 2016

Available Online:

10 May 2016
A B S T R A C T

Tourniquets used repeatedly on patients for blood sampling are a potential source of Nosocomial infections. Reusable venesection Tourniquets are often used consecutively on multiple patients without disinfection between uses. The present study was conducted to isolate the potentially pathogenic bacteria from reusable Tourniquets and to study their antibiotic resistance pattern. The study was conducted in King George Hospital (KGH), tertiary care teaching hospital in Vizag, Andhra Pradesh. Swabs from 50 Tourniquets of various areas in the hospital were taken for the study in December 2015. The samples were transported immediately to the lab in BHI broth and inoculated onto sheep blood agar and McConkey's agar, incubated at $37^{\circ} \mathrm{C}$ for 24 to 48 hours. Isolation and identification of the organisms were done by a standard procedure in the laboratory. Antibiotic sensitivity testing was done by Kirby-Bauer disc diffusion method on Muller Hinton Agar. Cefoxitin (30mcg) was used to detect MRSA and Ceftazidime and Ceftazidim+Clavulonate $(30 / 10 \mathrm{mcg})$ discs were used for ESBL producers and the zones of inhibition were interpreted as per CLSI guidelines. Out of the 50 Tourniquets, 8 were from sample collection sites, 9 from ICU's, 2 from casualty and 31 from various wards. Potentially pathogenic bacteria were isolated from 36 (72\%) Tourniquets out of 50 and non-pathogenic environmental commensals were isolated from $14(28 \%)$. Gram positive cocci were the predominant isolates 19 (52.8\%) followed by gram-negative bacilli 17 (47.2\%). Among total isolates 44.4\% and among GPC 84.2\%were staph aureus and 13.6\% (3) were enterococci. Among GNB, klebsiella species were predominant (10) followed by E.coli (5), Pseudomonas species (2) and acinetobacter species (2). MRSA was detected in 2 (12.5\%) strains of Staph aureus and ESBLs were detected in 3 (17.6\%). All the 3 Enterococci were sensitive to vancomycin. 1. Tourniquets are a potential reservoir and vehicle for the spread of nosocomial infections, including MROs. 2. Regular surveillance and sterilisation or disinfection policy for Tourniquets are recommended in Infection Control programme to decrease hospital acquired infections and multi-drug resistant organisms.

\section{Introduction}

Tourniquets used repeatedly on patients for blood sampling are a potential source of
Nosocomial infections (Zara Mehmood et al., 2014). Reusable venesection 
Tourniquets are often used consecutively on multiple patients without disinfection between uses. Hospital infection control policies attempt to minimise cross transmission of Multi-Resistant Organisms (MROs), which include MethicillinResistant Staphylococcus aureus (MRSA), Vancomycin-Resistant Enterococci (VRE), and Enterobacteriaceae harbouring transmissible Extended-spectrum betalactamases( ESBLs) and Metallo-betalactamases (MBLs). (Angle N Pinto et al., 2011) Surfaces such as keyboards, (Simmons, 2006) stethoscopes, (Marinella et al., 1997; Bernard et al., 1999; Varghese et al., 1999; Kennedy et al., 2003) ties, (Dixon, 2000; Ditchburn, 2006; Day, 2006; Biljan et al., 1993; Steinlechner et al.,) 2002 lanyards, and Tourniquets, have the potential to act as fomites and can harbour pathogenic microorganisms. The present study was conducted to isolate the potentially pathogenic bacteria from reusable Tourniquets and to study their antibiotic resistance pattern.

\section{Materials and Methods}

The study was conducted in $\mathrm{KGH}$, tertiary care teaching hospital in Vizag, Andhra Pradesh. Swabs from 50 Tourniquets of various areas in the hospital were taken for the study in December 2015. To obtain the samples swab sticks moistened with sterile saline were rotated over both sides of the Tourniquets at the distal and proximal ends which are most frequently touched by contaminated fingers. The samples were transported immediately to the lab in BHI broth and inoculated onto sheep blood agar and McConkey's agar incubated at $37^{\circ} \mathrm{C}$ for 24 to 48 hours, Isolation and identification of the organisms were done by a standard procedure in the laboratory. Antibiotic sensitivity testing was done by Kirby-Bauer disc diffusion method on Muller Hinton
Agar. Cefoxitin disc (30 mcg) was used to detect MRSA and Ceftazidime(30mcg) and Ceftazidim+Clavulonate $(30 / 10 \mathrm{mcg})$ discs were used for ESBL producers and the zones of inhibition were interpreted as per CLSI guidelines

\section{Results and Discussion}

Out of the 50 Tourniquets, 8 were from sample collection sites, 9 from ICU's, 2 from casualty and 31 from various wards (Table $1)$.

Potentially pathogenic bacteria were isolated from $36(72 \%)$ Tourniquets out of 50 and non-pathogenic environmental commensals were isolated from 14 (28\%). Gram positive cocci were the predominant isolates 19 (52.8\%) followed by gram-negative bacilli $17(47.2 \%)$. Among total isolates $44.4 \%$ and among GPC $84.2 \%$ were Staph aureus and $13.6 \%$ (3) were Enterococci.

Among GNB Klebsiella species were predominant - 10 (27.8\%), followed by E.coli - 5 (13.9\%), Pseudomonas species - 2 $(13.6 \%)$ and Acinetobacter species - 2 (13.6\%). (Table 2).

MRSA was detected in $2(12.5 \%)$ strains of Staph aureus and ESBLs were detected in 3 $(17.6 \%)$. All the 3 Enterococci were sensitive to vancomycin. The two MRSA strains isolated were, one from ICU and one from the ward. Out of the three ESBL strains, two were isolated from ICUs and one from the ward.

Many Tourniquets had mixed pathogenic and non-pathogenic bacterial growth.

After sterilisation by autoclave for the Tourniquets which are autoclavable and disinfecting other Tourniquets with $70 \%$ alcohol, the swabs were collected and 
processed for culture. All the swabs were sterile, as there was no growth.

Tourniquets are often used consecutively on multiple patients, regardless of their infective status and with no disinfection between uses, although the WHO, the National Association of Phlebotomists in England and Australian Healthcare guidelines (National Health and Medical Research Council, 2010) recommended that Tourniquets and other non-critical items be cleaned between uses. Numerous studies have indicated reusable venesection Tourniquets as a potential source of significant bacterial colonisation and MROs. (Pinto et al., 2011; Elhassan et al., 2012)

Table.1 Tourniquet Collection Data

\begin{tabular}{|l|l|c|}
\hline S.No & Area & No of Tourniquets \\
\hline 1. & Sample Collection Sites & 8 \\
\hline 2. & ICU's & 9 \\
\hline 3. & Wards & 31 \\
\hline 4. & Casualty & 2 \\
\hline Total & & 50 \\
\hline
\end{tabular}

Table.2 Microbial Colonisation of Tourniquets

\begin{tabular}{|l|l|c|c|c|c|c|}
\hline S.No & $\begin{array}{l}\text { Tourniquets } \\
\text { collected }\end{array}$ & Wards & $\begin{array}{c}\text { Sample } \\
\text { Collection }\end{array}$ & ICUs & Casualty & Total \\
\cline { 3 - 6 } & & 31 & 8 & 9 & 2 & 50 \\
\hline 1. & $\begin{array}{l}\text { Micrococci }+ \text { bacillus } \\
\text { species }\end{array}$ & 5 & 1 & 0 & 0 & 6 \\
\hline 2. & CONS & 4 & 2 & 2 & 0 & 8 \\
\hline 3. & Staph aureus & 10 & 2 & 3 & 1 & 16 \\
\hline 4. & Enterococci & 3 & 0 & 0 & 0 & 3 \\
\hline 5. & Klebsiella spp & 4 & 2 & 2 & 1 & 9 \\
\hline 6. & E.coli & 2 & 1 & 1 & 0 & 4 \\
\hline 7. & Pseudomonas spp & 2 & 0 & 0 & 0 & 2 \\
\hline 8. & Acinetobacter spp & 1 & 0 & 1 & 0 & 2 \\
\hline
\end{tabular}

In the present study 36 (72\%) Tourniquets showed bacterial growth which correlates with Angle N Pinto et al who reported $61 \%$. Staph aureus was the predominant isolate $(44.4 \%)$ which correlates with Zara Mehmood et al who reported $43 \%$. In the present study, GNB were isolated in 47.2\% which correlates with Angle $\mathrm{N}$ Pinto et al who reported $44.5 \%$. MRSA was isolated in $12.5 \%$ which correlates Zara Mehmood et al who reported 18.2\% of MRSA. ESBLs were isolated in $17.6 \%$ in the present study whereas Angle $\mathrm{N}$ Pinto et al reported around 5\%.
In conclusion, tourniquets are a potential reservoir and vehicle for the spread of nosocomial infections, including MROs. Regular surveillance and sterilisation or disinfection policy for Tourniquets are recommended in Infection Control programme to decrease hospital acquired infections and multi-drug resistant organisms.

\section{References}

Zara Mehmood, Syed Muhammad Mubeen, Muhammad Shehzad Afzal, Zainab Hussain, Potential 
Risk of Cross-Infection by Tourniquets: A Need for Effective ControlPractices in Pakistan, Int. $J$. Prev. Med., 5(9): 1119-1124.

Angle, N., Pinto, Phan, T., Sala, G., Cheong, E.Y., Siarakas, S., Gottlieb, T. 2011. Reusable venesection tourniquets: a potential transmission of multiresistant organisms. the source of the hospital, Med. J. Aust., 195(5): 276-9.

Fellowes, C., Kerstein, R., Clark, J., Azadian, B.S. 2006. MRSA on tourniquets and keyboards. $J$. Hosp. Infect., 64: 86-88.

Simmons, N. 2006. Computer keyboards and the spread of MRSA. J. Hosp. Infect., 64: 88.

Marinella, M.A., Pierson, C., Chenoweth, C. 1997. The stethoscope. A potential source of nosocomial infection? Arch. Intern. Med., 157: 786-790.

Bernard, L., Kereveur, A., Durand, D., et al. 1999. Bacterial contamination of hospital physicians' stethoscopes. Infect. Control Hosp. Epidemiol., 20: 626-628.

Varghese, D., Patel, H. 1999. Hand washing. Stethoscopes and white coats are sources of nosocomial infection. BMJ, 319: 519.

Kennedy, K.J., Dreimanis, D.E., Beckingham, W.D., Bowden, F.J. 2003. Staphylococcus aureus and stethoscopes [letter]. Med. J. Aust., 178: 468.

Dixon, M. 2000. Neckties as vectors for nosocomial infection. Intensive Care Med., 26: 250.

Ditchburn, I. 2006. Should doctors wear ties? J. Hosp. Infect., 63: 227-228.

Day, M. 2006. Doctors are told to ditch "disease spreading" neckties [news]. BMJ, 332: 442.
Biljan, M.M., Hart, C.A., Sunderland, D., et al. 1997. Multicentre randomised double-blind crossover trial on contamination of conventional ties and bow ties in routine obstetric and gynaecological practice. $B M J, 307$ : 1582-1584.

Steinlechner, C., Wilding, G., Cumberland, N. 2002. Microbes on ties: do they correlate with wound infection? Bull. R. Coll. Surg. Engl., 84: 307-309.

Kotsanas, D., Scott, C., Gillespie, E.E., et al. 2008. What's hanging around your neck? Pathogenic bacteria on identity badges and lanyards. Med. J. Aust., 188: 5-8.

Golder, M., Chan, C.L.H., O'Shea, S., et al. 2000. Potential risk of crossinfection during peripheral venous access by contamination of tourniquets. Lancet, 355: 44.

Berman, D.S., Schaefler, S., Simberkoff, M.S., Rahal, J.J. 1986. Tourniquets and nosocomial methicillinresistant Staphylococcus aureus infections. N. Engl. J. Med., 315: 514-515.

Ahmed, S.M., Ahmad, R., Case, R., Spencer, R.F. 2009. A study of microbial colonisation of orthopaedic tourniquets. Ann. $R$. Coll. Surg. Engl., 91: 131-134.

World Health Organization. Geneva: World Health Organization; 2010. [Last accessed on 2013 Feb 02]. WHO Guidelines on Drawing Blood: Best Practices in Phlebotomy. Available from: http://www.whqlibdoc.who.int/pub lications/2010/9789241599221_en g.pdf .

Pratt, R.J., Pellowe, C., Loveday, H.P., Robinson, N., Smith, G.W., Barrett, S., et al. 2001. The epic 
project: Developing national evidence-based guidelines for preventing healthcare associated infections. Phase I: Guidelines for preventing hospital-acquired infections. Department of Health (England) J. Hosp. Infect., 47(Suppl): S3-82.

National Health and Medical Research Council. Canberra: Australian Government; 2010. [Last accessed on 2013 Feb 02]. Australian Guidelines for the Prevention and Control of Infection in Healthcare. Available from: http://www.nhmrc.gov.au/_files_n hmrc/publications/attachments/cd3 3_complete.pdf.

Pinto, A.N., Phan, T., Sala, G., Cheong,
E.Y., Siarakas, S., Gottlieb, T. 2011. Reusable venesection tourniquets: A potential source of hospital transmission of multiresistant organisms. Med. J. Aust., 195: 276-9.

Elhassan, H.A., Dixon, T. 2012. MRSAcontaminated venepuncture tourniquets in clinical practice. Postgrad. Med. J., 88: 194-7.

Fellowes, C., Kerstein, R., Clark, J., Azadian, B.S. 2006. MRSA on tourniquets and keyboards. $J$. Hosp. Infect., 64: 86-8.

Kane, L., Krischock, L., Lucas, C. 2011. Phlebotomy tourniquets-vectors for bacterial pathogens. Arch. Dis. Child., 96(Suppl 1): A47-8.

\section{How to cite this article:}

Siva Kalyani, C., Ramalakshmi Koripella and Sk. Najar Valli. 2016. Isolation of Potentially Pathogenic Bacteria from Reusable Venesection Tourniquets in a Tertiary Care Hospital. Int.J.Curr.Microbiol.App.Sci. 5(5): 153-157. doi: http://dx.doi.org/10.20546/ijcmas.2016.505.016 